\title{
Analysis of Garlic Commodity Competitiveness and Impact of Government Policy in Indonesia
}

\author{
Saptana $^{1, *}$, Atika Dyah Perwita ${ }^{2}$, and Syahrul Ganda Sukmaya ${ }^{3}$ \\ ${ }^{1}$ Indonesian Center for Agricultural Socio Economic and Policy Studies, 16114 Bogor, Indonesia \\ ${ }^{2}$ Universitas Islam Negeri Walisongo Semarang, Faculty of Tarbiyah and Teacher Training, 50185 \\ Semarang, Indonesia \\ ${ }^{3}$ Universitas Jenderal Soedirman, Faculty of Agriculture, 53122 Purwokerto, Indonesia
}

\begin{abstract}
Indonesia's government is currently developing garlic commodities in several areas of highland dry land production centres to reduce dependence on imports (94\%) from domestic needs. This paper aims to: (1) analyse the benefits of garlic farming financially (private) and economically (social); (2) analyse the competitiveness of garlic farming, both from the perspective of competitive advantage and comparative advantage; (3) review the impact of government policy on garlic farming system; and (4) formulate incentive policies in garlic development. The analysis method was conducted using the Policy Analysis Matrix (PAM) to see Indonesian garlic's competitive position globally. The study area includes Cianjur Regency, West Java; Karang Anyar, Central Java; Pasuruan, East Java; and East Lombok, West Nusa Tenggara. The analysis results showed that garlic farming is financially profitable, but economically less profitable or not profitable. Garlic farming has a competitive advantage but less or no comparative advantage. The value of DRCR $>1$ shows that Indonesia does not have a comparative advantage in producing garlic. The policy implication is that if Indonesia continues to reduce dependence on imported garlic, it will require breakthroughs in advanced innovation, integrated regional development, agricultural infrastructure support, institutional strengthening of farmers, and farmers' incentive policies.
\end{abstract}

\section{Introduction}

\subsection{Research Background}

Garlic commodity (Allium sativum L.) is one of the vegetable commodities that serve as a cooking seasoning that cannot be substituted with other seasoning products. Currently, the Indonesian government is promoting an increase in domestic garlic production to increase dependence on imports reaching 472.92 thousand tons (94\%) domestic needs [1]. Garlic commodity is seen as a strategic food commodity because it is an unconstitutional spice and

\footnotetext{
*Corresponding author: saptana.07@.gmail.com
} 
saves foreign exchange where the import value of this commodity reaches 4.5 trillion per year.

Garlic production centres in Java Island are located in Central Java Province with $40.49 \%$, East Java by $6.56 \%$ and West Java by $6.33 \%$. While outside Java, there is in West Nusa Tenggara with a contribution of $39.45 \%$, West Sumatra by $2.48 \%$, and East Nusa Tenggara by $1.08 \%$. The total production of garlic in 2019 amounted to 88,817 tons, and the estimated consumption of garlic in 2020 amounted to 498.94 thousand tons [1]. In 2020, the deficit in garlic availability reached 393.65 thousand tons and increased in 2021, the deficit of garlic supply reached 408.02 thousand tons. A considerable shortage of garlic supply from year to year is met through imports from China, India, Taiwan, and the United States [1].

Rapid changes in technology adoption, society's demands, and the strategic environment dynamics are challenges for companies or manufacturers in maintaining and achieving a competitive advantage in the market in the past decade [2]. Companies or manufacturers face increasing pressure to keep their competitive advantage in the market [3]. Companies or manufacturers should pay attention at the regional and global level to improve efficiency, quality, service, and customer loyalty programs that demand the high power of innovation and creativity [4]. Consequently, traditional methods that are still used and preserved by most companies or manufacturers are considered irrelevant to the dynamics of increasingly competitive market conditions [5]. Companies' or manufacturers' attention is needed to change their business activities to be more innovative and creative to come out of the failure to compete in domestic, regional, and global markets [6].

The global value chain/GVC refers to the advancements in the value chain of several agricultural goods listed under horticultural items [7-9]. [10] Reveals that global trade reforms can create new opportunities and involve adjustment costs for poor farmers. It says that access to global markets can provide higher average income yields for farmers who specialize in producing export crops. It may also generate more competition, especially for imported substitution commodities, and have the opportunity to reduce labour demand, especially the poor.

The characteristics of garlic commodities cultivation in Indonesian production hubs are as follows: (a) it is an imported commodity and its development is an import substitution commodity; (b) garlic commodity farming is cultivated on highland dry land, especially in the dry season; (c) the scale of the business undertaken is relatively limited, and the encouragement of garlic development programs by the government; (d) generally farmers prefer other commodities because they are seen as more profitable; (e) the application of breeding, cultivation, and post-harvest technology is still low due to lack of technological support and agro ecological stability; (f) the development of garlic areas based on farmer cooperation is still far from the government's expectations; and ( $\mathrm{g}$ ) garlic production is generally bulbous and small-sided to lose the competition with imported garlic commodities.

When evaluating the competitiveness of garlic commodities, the following research issues must be addressed: (1) How is garlic farming's profitability level in Indonesia's central garlic production areas? (2) What is the position of garlic competitiveness both from the perspective of competitive and comparative advantages that began to be developed in Indonesia in the global market; (3) If it has competitiveness, has the existing competitive position a future?; and (4) What policy choices are available to garlic farmers to boost their production and competitiveness? 


\subsection{Research Purpose}

The purpose of this study is to: (1) Examine the economics of garlic cultivation on a private and social level; (2) Analysing garlic commodity farming's competitive advantage and comparative advantage; (3) Review the impact of government policies in the garlic commodity farming system; and (4) Develop sustainable garlic commodities farming incentive policies.

\section{Research Methods}

\subsection{Research Framework}

The competitiveness of a product in the global market is defined by the total performance of the relevant product value chain at the local, regional, and global levels [11,12]. Competitiveness is directed to support companies, industries, regions, or countries to create a relatively high level of income while maintaining the ability to compete globally [13]. The capacity to generate value-added products through upgrading and strengthening local economic institutions, as well as the role of industry stakeholders, is determined at the local level; however, the input-output structure of governance value chains, geographic scope, and management structure influenced by company and industry stakeholder leadership are determined at the regional and global levels [12].

The most relevant issue in relations between countries is reorganizing the production and trade system to benefit national economic development. Policy in production should be returned to the comparative advantages of a country, where Indonesia has an advantage in the agribusiness and agro-industry sector [14,15]. According to Ricardo's comparative advantage theory, even if a country lacks an absolute advantage in producing two separate items in compared to other countries, mutually advantageous trade can still exist as long as the two countries have a price differential relative to no trade at all [16-18].

Heckscher-Ohlin's theory of trading patterns states that [16,19]: "Commodities in production require production factors (abundant) and production factors (rare) in export in exchange for goods that require production factors in the opposite proportion. So indirectly the abundant production factors in exports and the rare production factors in imports" [16,20]. Esterhuizen [21] define competitiveness "as the ability of a sector, industry or firm to compete successfully to achieve sustainable growth within the global environment while earning at least the opportunity cost of return on resources employed."

Operationally competitive advantage can be interested as: "The ability to deliver goods and services at the time, place and form sought by the buyer is in both the domestic and international market at a price and good or better than those of other potential suppliers, while earning at least opportunity cost on resources employed" [22-24]. To determine the competitiveness and influence of government policies on garlic cultivation in Indonesian production centres, we employed Monke and Pearson's Policy Analysis Matrix (PAM) methods, whose application has been widely deployed among others [25-30].

\subsection{Research Location and Sample Respondents}

This paper is mainly directed to analyse the competitive position of Indonesian garlic commodities in the global market. The location of the example was taken in 5 (Five) districts of garlic commodity production centres of highland dry land in Indonesia, namely: (a) Cianjur Regency, West Java; (b) Karanganyar Regency, Central Java; (c) Pasuruan 
Regency, East Java; and (d) East Lombok Regency, West Nusa Tenggara. Most garlic farming businesses are only planted in the dry season; only in Pasuruan Regency are found farmers who plant both in the dry and wet season. The research was conducted through Focus on Group discussion (FGD) in January-April 2020.

This analysis was conducted with a Policy Analysis Matrix (PAM) approach that emphasizes data accuracy through limited survey interviews and group interviews in each production centre area in Indonesia. The number of respondents who were interviewed and followed the FGD at each location example of 5-10 respondents because the number of respondents who worked on garlic is minimal. The withdrawal of sample respondents using stratified random sampling method, stratification is done based on the area of farming, representing farmers of large, medium, and narrow land. Besides, it is also considered the composition of the existence of advanced farmers is wide-ranging, and farmers, in general, are small. Respondents were members of a farmer's group located in the central area of garlic production. Garlic farming study is conducted on a per-production cycle or per hectare basis.

\subsection{Analysis Methods}

Data analysis is performed to answer three main objectives, while the fourth goal is answered descriptively qualitatively by synthesizing analysis of goals one, two, and three. By using PAM as an analysis tool, economic activity can be viewed from two perspectives, namely: (a) financial perspective or individual (financial perspective/private perspective) and (b) social or economic perspective [31-33]. Comparative advantage in garlic farming is farming's ability to produce output value or regional profit on the cost of the sacrifice of domestic inputs used. In contrast, the competitive advantage is garlic farming's ability to generate output value or profit on the cost of sacrifice for tradable inputs used [34].

Sequentially PAM calculation steps consist of four stages, namely: (1) determination of physical input (input)-output (output) completely; (2) shadow price (social price) from input and output; (3) Detachment of constantly on costs under down home Furthermore outside segments (tradable inputs), and in addition ascertaining the amount from claiming receipts Monetarily (private) What's more monetarily (social); and (4) calculate and analyze a total of 13 indicators that can be generated from PAM. Two main things must be explained before calculating PAM and the resulting indicators, namely the detachment for cosset parts under tradable products parts What's more household factors, and additionally shadow value appraisal (social price) inputs What's more outputs, and additionally the division about cosset segments under tradable enter segments What's more provincial factors.

\subsection{Tradable Input and Domestic Factor Cost Component Allocation}

On PAM analysis, inputs utilized within those preparation methodology need aid allocated under (a) tradable inputs (tradable goods) and (b) household variables (non-tradable goods). The To begin with classification from claiming handling inputs might be exchanged on the universal market, same time those second class inputs need aid non-tradable inputs on the worldwide showcase. As stated by (Kadariah 1978; Gittinger, 1986) [35,36], purported tradable merchandise are products that are: (1) currently exported or imported; (2) An substitute nearly identified with Different sorts exported or imported; What's more (3) items other than those over What's more ensured by those government, which might make exchanged internationally.

According to Monke and Pearson [31-33], Two methodologies need aid used to dispense expenses under tradable enter Also down home element components, to be 
specific thorough methodology Furthermore regulate approach. Pam examination in this paper utilization a regulate methodology where each tradable input is incorporated into foreign components. The argument is that any oversupply can be sold to the global market and vice versa if a shortage can be supplied from the worldwide market.

Thus in PAM analysis on garlic farming at the research site used a direct approach. Those regulate methodology will vegetable items need been generally connected $[25,26,34]$ In this paper, those yield of garlic is expected will be 100 percent tradable merchandise. In inputs acknowledged 100 percent tradable are garlic seeds, urea fertilizer, SP-36, KCL, NPK, PPC, Also pesticides. On the different hand, inputs accepted should be 100 percent Likewise household Components need aid natural fertilizer, labor, land rent value, also money investment.

According to the results of interviews with various trade actors at the research site, the composition of the allocation of marketable goods and domestic factors of production for garlic commodity transport actions is based on the results of interviews with various trade actors at the research site, where for labour costs associated with the procedure of transportation are considered a domestic factor (domestic Factor), and transportation costs are considered a component of tradable inputs (tradable inputs), and transportation costs are considered as a component of tradable inputs ( It is based on information gathered through direct interviews with garlic enterprises that the cost of processing post-harvest garlic commodities may be divided into tradable components and domestic elements. The cost of processing post-harvest garlic commodities is comprised of materials introduced as tradable inputs and labour inserted as domestic components of production and distribution. For garlic cultivation, Appendix 1 breaks down the cost allocation results into tradable inputs and domestic factors.

\subsection{Social Pricing}

In PAM, for each output (input) and input (output) is set two levels of price, namely actual price in the market (private price) and shadow price (social price). Private price is the level of market price received by farmers in the selling of commodities or paid for production elements. Gittinger [36] defines shadow prices as prices that occur in an economy in perfect competition or a state of balance. The cost balance condition is the same as the market price; in reality, it is difficult to find, so to obtain a value that is close to the opportunity cost or social price needs to be adjusted to the prevailing market price. In this study, the shadow price for goods traded was approached with a border price. For goods that have been exported used price f.o.b. (free on board) and for imported goods used the price of c.i.f (cost insurance freight). Distortions for the most part focus shadow costs because of administration arrangements for example, such that subsidies, taxes, least wage determinations, estimating policies, What's more different approaches [36]. In down home variables would approached for the cosset of the good fortune or the Normal cost in each area. The component about computation of shadow costs to garlic cultivating will be as takes after:

1. The shadow price of garlic seeds is approached with the average price of seeds in each location, furthermore, done calculations for each area of the garlic production center by issuing a value-added tax of $10 \%$ and reducing the transfer cost from the port to large traders so that garlic seeds' social price was obtained.

2. Urea fertilizer payment is on the basis of the fob price of U\$ $0.134,-/ \mathrm{kg}$, then converted by dollar exchange rate against rupiah, IDR. 14,173 -/U\$ so that it becomes IDR. 1,899 $-/ \mathrm{kg}$, then calculated for each area of garlic production centre by factoring in export taxes, value-added taxes, and transfer fees from the port to large merchants, the social price of urea fertilizer may be determined. 
3. The shadow price of SP-36 fertilizer is calculated using a CIF price of U\$ $0.231,-/ \mathrm{kg}$, then converted with the exchange rate of dollars against rupiah amounting to IDR.14,173,-/U\$ so that it becomes IDR 3,274,-/kg, then do the calculation for each garlic production centre area by taking into account import tariffs, value-added taxes, and transfer fees from ports to large traders and transfer fees from large traders to farmers, level so that social prices of SP-36 fertilizer are obtained.

4. The shadow price of NPK/PONSKA fertilizer is calculated using the CIF price and then converted to dollars using the current exchange rate of IDR 14,173/U\$. It incorporates import tariffs, value-added taxes, and port-to-port transfer fees for large dealers.

5. The shadow price of KCL fertilizer is calculated using the cif price, which is US $0.308,-/ \mathrm{kg}$, and then converted to IDR $4,365,-/ \mathrm{kg}$ using the dollar exchange rate against the rupiah, which is IDR $14,173,-/ \mathrm{U} \$$. The shadow price is then calculated for each area of the garlic production centre, taking into account import tariffs, value-added tax, as well as transfer fees from ports to large traders and large traders to farmers.

6. The shadow price of organic fertilizer/manure, Liquid Complementary Fertilizer (PPC), and agricultural lime because many types and various contents are approached using the actual average price in each area of garlic production centres.

7. The real average price in each region of garlic production centres is used to calculate the shadow price of pesticides, which is then decreased by $10 \%$. Pesticides provide social costs.

8. The shadow price of mulch plastic is approached with the actual average price in each area of garlic production canter, then reduced import tariff by $10 \%$ and value added tax $10 \%$, so that the social price of plastic mulch is obtained.

9. The price of garlic output is based on fob price of U\$ $1,157 / \mathrm{kg}$, then converted at the exchange rate of dollar to rupiah of IDR $14,173 / \mathrm{U} \$$ so that it becomes IDR.16,398/kg dry because the import in the dry form then to be able to compare it must be converted with a conversion factor of $60 \%$ from wet to dry so that the price of IDR $9,386 / \mathrm{kg}$ is obtained, then the calculation for each location by taking into account the cost of import permits, value-added tax, and transfer fees from the port to the big traders so that the social price of garlic output is obtained in the wet form at the farmer level.

10. The shadow price of land is approached with the rental value of land in each canter of garlic production; it is based on that the mechanism of the land market goes well indicated by the running of land leases.

11. The shadow price of labour is calculated using the actual wage value applicable at each research site of garlic production centres in each location because the labour market mechanism is running well.

12. Those shadow cost for those money investment rate (premium rate) utilization those true interest rate, which is computed Toward diminishing those genuine investment rate with the swelling rate that occurs, in view The majority garlic farmers entry will BRI Furthermore BRI unit At that point the genuine investment rate utilizing those BRI kupedes investment rate about 3. $31 \%$ for every 4 months, for an swelling rate about $0.55 \%$ for every month alternately $2.2 \%$ for every 4 months thereabouts that the shadow cost about capital investment is got $1.31 \%$ for every developing season (4 months).

13. The shadow cost of the rupiah conversion scale against that dollar utilizing the Normal conversion scale in 2019 is dependent upon that Indonesia taken after the floating conversion scale. Those shadow value of the rupiah conversion scale against the dollar added up with IDR 14,173/U\$.

The results of the assessment of the shadow price of inputs and outputs of garlic farming are presented in Annexes 2.1 and 2.2. 


\subsection{PAM Matrix Preparations}

The PAM calculating step is divided into four phases: (1) calculation of physical inputsoutputs solely based on economic activity as assessed in Tables 3 to 7; (2) dividing all expenses into tradable inputs and domestic factor components (Appendix 1); (3) shadow price assessment of the input and output of Appendix 2.1 and Appendix 2.2; (4) compile and calculate pam analysis (Appendix 3.1. - 3.6), and various indicators resulting from PAM analysis.

Table 1. Policy Analysis Matrix (PAM) used for analysis

\begin{tabular}{|l|c|c|c|c|}
\hline \multirow{2}{*}{ Description } & \multirow{2}{*}{ Revenue } & \multicolumn{2}{|c|}{ Cost } & \multirow{2}{*}{ Profit } \\
\cline { 3 - 4 } & & Tradable input cost & Domestic factor cost & \\
\hline Private Cost & $\mathrm{A}$ & $\mathrm{B}$ & $\mathrm{C}$ & $\mathrm{D}$ \\
\hline Social Cost & $\mathrm{E}$ & $\mathrm{F}$ & $\mathrm{G}$ & $\mathrm{H}$ \\
\hline Effect of divergence and policy & $\mathrm{I}$ & $\mathrm{J}$ & $\mathrm{K}$ & $\mathrm{L}$ \\
\hline
\end{tabular}

PAM matrix preparation is done after all farming data at the level of farmers and business actors obtained. PAM grid preparation is completed Toward utilizing a inputoutput structure In those level of cultivating What's more business performing artists. With this calculation can be obtained both financial or private or economic or social benefits. The impact of government policy applied to input, output, and input and output fields can be simultaneously calculated.

PAM analysis provides information about the profitability of farming, competitiveness of a commodity both from economic efficiency (comparative advantage) and financial efficiency (competitive advantage), the impact of government policy on the garlic farming system. PAM table can be seen inPAM matrix table in table 1.

Description: $\mathrm{I}=\mathrm{A}-\mathrm{E} ; \mathrm{J}=\mathrm{B}-\mathrm{F} ; \mathrm{K}=\mathrm{C}-\mathrm{G} ; \mathrm{L}=\mathrm{D}-\mathrm{H}$

1. Private Profitability $(\mathrm{PP}): \mathrm{D}=\mathrm{A}-(\mathrm{B}+\mathrm{C})$;

2. Social Profitability $(\mathrm{SP}): \mathrm{H}=\mathrm{E}-(\mathrm{F}+\mathrm{G})$;

3. Private Cost Ratio : $\mathrm{PCR}=\mathrm{C} /(\mathrm{A}-\mathrm{B})$;

4. Domestic Resource Cost Ratio : $\mathrm{DRCR}=\mathrm{G} /(\mathrm{E}-\mathrm{F})$;

5. Output Transfer: OT $=\mathrm{A}-\mathrm{E}$;

6. Nominal Protection Coefficient on Tradable Output : $\mathrm{NPCO}=\mathrm{A} / \mathrm{E}$;

7. Transfer Input : IT $=\mathrm{B}-\mathrm{F}$;

8. Nominal Protection Coefficient on Tradable Input : NPCI $=\mathrm{B} / \mathrm{F}$;

9. Transfer factor: $\mathrm{FT}=\mathrm{C}-\mathrm{G}$;

10. Effective Protection Coefficient : $\mathrm{EPC}=(\mathrm{A}-\mathrm{B}) /(\mathrm{E}-\mathrm{F})$;

11. Transfer net : $\mathrm{NT}=\mathrm{D}-\mathrm{H}$;

12. Profitability Coefficient L PC $=\mathrm{D} / \mathrm{H}$;

13. Subsidy Ratio to Producer: $\mathrm{SIDR}=\mathrm{L} / \mathrm{E}$.

\section{Results and Discussion}

\subsection{Garlic Commodity Competitiveness Analysis}

Some experts argue that competitiveness is not an economic concept but a business concept $[22,23]$. However, some economists inteIDRret competitive advantage as a combination of market distortion and comparative advantage [31,32]. The importance of in cooperating analysis of competitive advantage strategies and business models to protect the competitive advantage resulting from the design of new business models. 


\subsubsection{Private and Social Costs and Benefits}

Based on the analysis of costs and financial benefits (private) shows that garlic farming in the dry land highlands in Indonesia is still profitable, most of which is only cultivated in the dry season, such as in Karanganyar, Central Java; Pasuruan, East Java; and East Lombok, West Nusa Tenggara. Meanwhile, garlic cultivation in the wet season is only found in Cianjur Regency, West Java and Pasuruan Regency, East Java. In general, social or economic benefits are lower when compared to financial or private benefits, and the benefits in the dry season are more significant than the profits in the wet season.

The highest private profit of garlic farming was found in Karanganyar Regency in the dry season with a profit in the dry season of IDR 50,788,316,-/ha/season, while the lowest profit found in Cianjur Regency only provided a profit of IDR 17,640,412/ha/season in the wet season. The results of the study of Kiloes and Hardiyanto [37] by comparing the advantages of farming with the average MSEs, the price of wet garlic for decent consumption is a minimum of IDR $15,000.00 / \mathrm{kg}$ while the price of a decent garlic seed is a minimum of IDR53,000.00/kg, and a maximum of IDR55,000.00/ $\mathrm{kg}$. The price can be used as a reference for the purchase of garlic at the farmer level to provide guarantees for farmers to continue farming garlic at a favourable selling price but still compete with imported garlic.

The highest amount of social or economic benefits of garlic farming is found in the dry land of the highlands in Karanganyar Regency with a profit in the dry season of IDR $9,465,236,-/$ ha/season. In contrast, the lowest in the wet season is found in Karanganyar Regency in the wet season, experiencing a negative profit of IDR $(26,790,476) /$ ha/season. This study's results are in parallel with the results of a study Dipokusumo [34], which concluded that garlic farming in East Lombok Regency is privately profitable at IDR $4,206,793$-/ha/season and social benefits are relatively limited to only IDR 1,080,224,/ha/season. The costs and benefits of private and social garlic farming in each location are presented in Table 2 .

Table 2. Financial benefits and economic benefits, PCR and DRC garlic farming highland dry land in Indonesia, 2019-2019/2020

\begin{tabular}{|c|l|r|r|r|r|}
\hline No. & \multicolumn{1}{|c|}{ District } & Private benefits (IDR) & $\begin{array}{c}\text { Social benefits } \\
\text { (IDR) }\end{array}$ & PCR & \multicolumn{1}{c|}{ DRCR } \\
\hline 1 & Cianjur: WS & $17,640,412$ & $4,528,242$ & 0.655 & 0.878 \\
\hline 2 & Karanganyar & & & & \\
\hline & a. Dry Season & $50,788,316$ & $9,465,236$ & 0.467 & 0.835 \\
\hline & b. Wet Season & $25,058,613$ & $(26,790,476)$ & 0.703 & 1.832 \\
\hline 3 & Pasuruan & & & & \\
\hline & a. Dry Season & $47,491,017$ & $10,319,652$ & 0.525 & 0.837 \\
\hline & b. Wet Season & $42,287,000$ & $(5,111,383)$ & 0.535 & 1.120 \\
\hline 4 & East Lombok : DS & $49,463,377$ & $(16,439,539)$ & 0.404 & 1.484 \\
\hline
\end{tabular}

\subsubsection{Competitive Advantage and Comparative Advantage}

There are two perspectives that can be used to analyze competitiveness, namely from the financial or private side as a competitive advantage, and from a social or economic perspective as a comparative advantage. Garlic farming in the central area of highland dryland production in Indonesia has good competitiveness from the perspective of competitive advantage shown the value of PCR coefficient $<1 \quad(0.404-0.703)$, but lacks comparative advantage the reflected coefficient value of DRCR is close to $1(0.835-0.878)$ and even $>1$ (1.120-1.832). The coefficient values of PCR $<1$ and DCR $<1$ indicate that garlic farming in the areas of highland dryland production centers in Indonesia still has a 
competitive and comparative advantage, but in some locations (Karanganyar WS, Pasuruan WS and East Lombok DS), no longer have a comparative advantage with the coefficient of DRCR $>1$ (1,120-1,832). This indicates that it takes less than one unit of the cost of domestic resources to produce one unit of value added output at private and social prices. For specific locations, it is necessary to be greater than the one-unit cost of domestic resources. In general, comparative advantage is lower than a competitive advantage, as well as the competitiveness of garlic farming businesses cultivated in the dry season is higher when compared to those cultivated in the wet season, as in the case of garlic farming Karanganyar and Pasuruan districts. The results of the analysis for the coefficient values of PCR and DRCR are in line with those conducted [34] on garlic farming in East Lombok with a coefficient value of PCR 0.72 and DRCR 0.90. According to agroecosystem and location, the amount of coefficient value of PCR and DRCR of garlic farming is presented in Table 2.

\subsection{Divergence Impact Analysis and Government Policy}

Indicators of the impact of divergence or government policy in the PAM Matrix on garlic farming in the areas of garlic production centers of the highland dry land consist of output transfer (output transfer / OT), input transfer (input transfer / IT), transfer factor (factor transfer / FT) and net transfer (net transfer/ NT). The relative measure is indicated by the nominal protection coefficient at the output (NPCO), the nominal protection coefficient at the input /NPCI, the adequate protection coefficient (EPC), the profitability coefficient (PC), and the ratio of subsidies to produce /SIDR in the garlic farming system.

\subsubsection{Impact of Government Policy on Output}

The impact of the policy in garlic output at the garlic production center of the highland dry land in Indonesia can be seen from the large value of the indicator transfer output (output transfer / OT) and nominal protection coefficient on output (NPCO). The form of government policy in the field of output can be in the form of trade policy that can be in the form of import quotas through import permits, import tariffs, value-added tax (VAT), input subsidy policy, and supporting policies in the form of agricultural infrastructure development. Garlic farming output transfer is the difference between receipts calculated on the financial price (private price) and receipts calculated based on social price. Nominal output protection coefficient (NPCO) is an indicator of output transfer calculated by dividing (ratio) from the receipt of garlic farming calculated based on financial price (private price) with receipts calculated based on social price.

Based on the analysis results presented in table 3, obtained the results of output transfer (OT) and NPCO for garlic farming in the central areas of garlic production of highland dry land in Indonesia. The analysis results showed that garlic farming on dry land plateau obtained a positive OT indicator value. NPCO value for garlic farming in the production center area in Indonesia obtained the value of NPCO coefficient $>1$. The positively marked output transfer value and NPCO coefficient value $>1$ reflect that garlic farming receives a higher actual price than the supposed price in perfectly competitive market conditions. In other words, on the output side, garlic farmers experience incentives in producing garlic.

The highest coefficient value of NPCO garlic farming was found on highland dry land in Karanganyar MH Regency with an NPCO value of 1,663 and East Lombok Mk Regency with an NPCO value of 1,503. Meanwhile, the lowest coefficient value of NPCO garlic farming was found on a dry land plateau in Cianjur Regency on MH with NPCO value of 1,227. This means that garlic farmers' output in the area of garlic production centers experienced incentives, where the least incentives received by farmers in Cianjur and the 
highest received farmers Karanganyar. The amount of coefficient value of NPCO garlic farming on a dry land plateau at the research site is presented in table Table 3.

Table 3. Transfer output value and Nominal Protection Coefficient on Garlic farming output in Indonesia, 2019-2019/2020

\begin{tabular}{|c|l|c|c|}
\hline No & District & $\begin{array}{c}\text { Output Transfer/OT } \\
\text { (IDR) }\end{array}$ & $\begin{array}{c}\text { Nominan Protection Coefisien } \\
\text { on Output (NPCO) }\end{array}$ \\
\hline 1 & Cianjur: WS & $22,290,236$ & 1.227 \\
\hline 2 & Karanganyar & & 1.467 \\
\hline & a. Dry Season & $44,907,325$ & 1.663 \\
\hline & b. Wet Season & $64,699,533$ & 1.474 \\
\hline 3 & Pasuruan & & 1.467 \\
\hline & a. Dry Season & $46,263,516$ & 1.507 \\
\hline & b. Wet Season & $44,907,325$ & \\
\hline 4 & East Lombok & $51,318,120$ & \\
\hline
\end{tabular}

\subsubsection{Impact of Government Policies on Input Field}

The impact of government policies on globally traded inputs (tradable inputs) on garlic farming in garlic production centers is indicated by the transfer value of inputs (transfer/IT inputs) and nominal protection coefficient on input (NPCI). Meanwhile, the impact of divergence or government policy contained in domestic factors is indicated by the transfer factor (FT).

Table 4. Value of IT, NPCI, and FT Garlic Commodity Farming per ha/season, in the central area of highland dryland production, in Indonesia, Dry Season (MK) 2019-Rainy Season (MH) 2019/2020

\begin{tabular}{|l|l|c|r|r|}
\hline No. & \multicolumn{1}{|c|}{ District } & $\begin{array}{c}\text { Input } \\
\text { Transfer/IT } \\
\text { (IDR) }\end{array}$ & $\begin{array}{c}\text { Nominal } \\
\text { Protection } \\
\text { Coefisien on } \\
\text { Input/NPCI }\end{array}$ & \multicolumn{1}{|c|}{$\begin{array}{c}\text { Factor Transfer } \\
\text { (IDR) }\end{array}$} \\
\hline 1 & Cianjur: WS & $8,406,600$ & 1.137 & 771,466 \\
\hline 2 & Karanganyar & & & $(3,428,555)$ \\
\hline & a. Dry Season & $7,012,800$ & 1.181 & 431,294 \\
\hline & b. Wet Season & $12,419,150$ & 1.190 & $(399,000)$ \\
\hline 3 & Pasuruan & & & 948,630 \\
\hline & a. Dry Season & $9,491,150$ & 1.275 & $(16,916,696)$ \\
\hline 4 & E. Wet Season & $8,025,650$ & 1.225 & \\
\hline
\end{tabular}

Forms of discretion on traded inputs (tradable inputs) and domestic factors (domestic factors) can be in the form of trade policy (import tariffs, import quotas/restrictions), input subsidies, taxes (value-added tax/VAT), while other forms of divergence may be due to market distortions, such as oligopsonistic market structures. Input transfer shows the difference between the cost of inputs that can be traded at a financial price (private price) and the cost of inputs traded at an economical price (social price). The ostensible assurance coefficient on input (NPCI) is an information move marker which is a proportion between tradable information costs determined dependent on private costs and tradable information costs determined at social costs. Data on its worth, NPCI and FT pointers on garlic cultivating on good country dry land agro ecosystems in Indonesia is introduced in Table 4.

The result of input transfer indicators for garlic commodities on highland dry land in Indonesia provides a positive IT value that varies from IDR 2,331,900,-/season/ha in East Lombok Regency and the highest amount of IDR 12,419,150,-/ha/season in Karanganyar Regency in the wet season. The amount of NPCI in garlic farming is highest in Pasuruan 
Regency in the dry season of 1,275 and the wet season of 1,225 , while the lowest NPCI is found in East Lombok Regency in the dry season of 1,035. This means a government policy on the side of tradable inputs that harm garlic farmers because farmers have to pay a higher price of tradable inputs than they should or compared to the perfectly competitive market structure.

The amount of NPCI in garlic farming is highest in Pasuruan Regency in the dry season of 1,275 and the rainy season of 1,225, while the lowest NPCI is found in East Lombok Regency in the dry season of 1,035 . This means a government policy on the side of tradable inputs that harm garlic farmers because farmers have to pay a higher price of tradable inputs than they should or when compared to the perfectly competitive market structure. Listening to government policies in the field of tariffs and subsidies of agricultural production facilities in recent years turned out to be a source of distortion is due to import permits and value-added taxes. In contrast, subsidies have been partially abolished even farmers face an oligopolistic market structure in dealing with the domestic and global fertilizer industry. However, in some research sites, there are still garlic farmers who receive subsidized fertilizer prices.

The analysis of transfer factors for garlic farming obtained figures from negative to positive with a limited amount. The largest transfer value factor was found in Pasuruan rainy season, with FT amounting to IDR 948,630,-/ha/season in the rainy season and the smallest FT found in East Lombok Regency amounting to -IDR16,916,696,-/ha/season in the wet season. This means that government policies or market distortions in domestic factors tend to harm garlic producer farmers because farmers have to pay domestic prices a factor slightly higher than the price that should be in perfectly competitive market conditions. The main source of price differences for the cost of domestic factors is sourced at capital interest because farmers have to pay more than the social price.

\subsubsection{Impact of Government Policy on Input-Output}

Table 5. Value of NT, PC, EPC and GARLIC FARMING SIDR in Indonesia, 20192019/2020

\begin{tabular}{|c|c|c|c|c|c|}
\hline $\begin{array}{l}\mathbf{N} \\
\mathbf{0 .}\end{array}$ & District & $\begin{array}{l}\text { Profitability } \\
\text { Coeficien/PC }\end{array}$ & $\begin{array}{c}\text { Net } \\
\text { Transfer/NT } \\
\text { (IDR) }\end{array}$ & $\begin{array}{l}\text { Effective Protection } \\
\text { Coefficient/EPC }\end{array}$ & $\begin{array}{l}\text { Ratio Subsidy to } \\
\text { Producer/SIDR }\end{array}$ \\
\hline 1 & $\begin{array}{l}\text { Cianjur: } \\
\text { WS }\end{array}$ & 3.896 & $13,112,170$ & 1.373 & 0.133 \\
\hline \multirow[t]{3}{*}{2} & $\begin{array}{l}\text { Karangar } \\
\text { yar }\end{array}$ & & & & \\
\hline & \begin{tabular}{l|l} 
a. Dry \\
Season
\end{tabular} & 5.366 & $41,323,080$ & 1.661 & 0.430 \\
\hline & $\begin{array}{l}\text { b. Wet } \\
\text { Season }\end{array}$ & -0.935 & $51,849,089$ & 2.623 & 0.531 \\
\hline \multirow[t]{3}{*}{3} & $\begin{array}{l}\text { Pasuru } \\
\text { an }\end{array}$ & & & & \\
\hline & $\begin{array}{l}\text { a. Dry } \\
\text { Season }\end{array}$ & 4.602 & $37,171,366$ & 1.582 & 0.508 \\
\hline & $\begin{array}{l}\text { b. Wet } \\
\text { Season }\end{array}$ & -8.273 & $47,398,383$ & 2.133 & 0.605 \\
\hline 4 & $\begin{array}{l}\text { East } \\
\text { Lombo } \\
\text { k }\end{array}$ & -3.009 & $65,902,916$ & 2.443 & 0.651 \\
\hline
\end{tabular}

The net transfer (NT), Effective Protection Coefficient (EPC), Profitability Coefficient (PC), and Subsidy Ratio to Producer (SIDR) values in the areas of highland dry land garlic 
production centres in Indonesia demonstrate the impact of divergence and government policy on overall inputs and outputs in these areas. As shown in Table 5, the analysis of the impact of government policy on inputs and outputs on garlic farming in Indonesia's garlic production centres is presented in a table format.

PC analysis results marked positive and negative tend to be positive on MK and negative in DS, as in the case in Karanganyar and Pasuruan districts, net transfer (NT) marked positive, EPC marked positive, and magnitude $>1(1,373-2,623)$, and SIDR marked positive and $<1$ in all research locations. The highest PC value was found on highland dry land in Karanganyar Regency in the dry season at 5,366, while the lowest PC value was found on highland dry land in Pasuruan rainy season with a PC value of $-8,273$. Government policy or market distortions in garlic farming as whole garlic farmers inputoutput provide incentives to farmers. This means that farmers get a bigger profit than they should if the market mechanisms compete perfectly.

NT value of garlic farming in the central area of garlic production on dry land highlands in Indonesia marked positive. The largest positively marked NT value was found on highland dry land in East Lombok Regency in MK, West Nusa Tenggara at IDR $65,902,916,-/$ ha/season, while the smallest positively marked NT value was found in Cianjur Regency at IDR 13,112,170,-/ha/season in the wet season. Government policies or market distortions that occur in inputs (tradable inputs and domestic factors) as well as overall output that provide incentives to garlic farmers as a whole.

The amount of EPC coefficient value for garlic farming is good on highland dry land in all positively marked research sites with a magnitude of $>1(1,373-2,623)$. The highest positive marked EPC value was found on highland dry land in Karanganyar Regency in the EPC rainy season of 2,623. In contrast, the lowest positive marked EPC value was found on highland dry land in Cianjur rainy season with an EPC value of 1,373. Government policy or market distortions that occur in garlic farming as a whole are incentivizing garlic farmers. This means that garlic farmers get effective protection from existing policies or market distortions compared to if the market mechanisms compete perfectly.

The coefficient value of SIDR in garlic farming in highland dryland agroecosystems at all research sites obtained positive SIDR coefficient values, both in the dry season and rainy season. The garlic farming system's SIDR value is marked positively is found in the agroecosystem of highland dry land in East Lombok Regency, West Nusa Tenggara, which is cultivated in the dry season. Meanwhile, the amount of SIDR value of garlic farming system marked as the lowest positive was found in the agroecosystem of highland dry land in Cianjur Regency, West Java, cultivated in the rainy season an SIDR value of 0.133 . This means that government policies or market distortions in the garlic farming system on dry land plateaus have a beneficial impact on garlic farmers because farmers receive a relatively large positive subsidy.

\section{Conclusions and Implications}

Based on the analysis of private costs and social benefits, garlic farming is financially profitable. The financial (private) benefits that farmers receive outweigh the social benefits. This analysis demonstrates that garlic producers in Indonesia are motivated to produce garlic because they earn a bigger profit margin than they should under perfectly competitive market conditions.

The results of the analysis showed that garlic farming in the central areas of highland dry land production in Indonesia has a competitive advantage with the value of PCR coefficient $<1$ (0.404-0.703), but lacks a comparative advantage that is reclaimed the coefficient value of DRCR is close to $1(0.835-0.878)$ and even some DRCR locations $>1$ $(1,120-1,832)$. The amount of domestic resources necessary to produce one unit of value- 
added is modest, but to produce units of value-added socially is at breakeven even greater than one. If viewed privately, Indonesia's local production expansion is more profitable., while if viewed socially more profitable by importing.

Government policies and market distortions are pushing farmers to expand garlic production. While farmers pay a higher trading input price than they should, they obtain a significantly greater selling price for garlic than they would under ideal market conditions. Meanwhile, farmers face disincentives due to domestic reasons, but these are rather minor. By and large, the impact of government regulations or market distortions on the inputs and production of garlic farming benefits farmers.

Important policy implications if the government still wants to reduce dependence on imports is the importance of advanced breakthrough technology (both nursery technology, cultivation technology and post-harvest technology), agricultural mechanization (alsintan cultivation assistance, processing and marketing of yields), integrated development of garlic areas, as well as optimal import tariff policy and abandon the import quota policy. Besides, the guarantee of the policy of availability of superior seeds and fertilizers in times of need and stabilization of garlic prices, especially during the harvest, is expected to provide incentives to farmers to farm garlic more productively, efficiently and competitively.

\section{References}

1. [KEMENTAN] Kementerian Pertanian, Outlook Bawang Putih Komoditas Pertanian Sub Sektor Hortikultura, Pusat Data dan Sistem Informasi Pertanian. Kementerian Pertanian. Jakarta, (2020)

2. Cancino CALa Paz AI, Ramaprasad A, Syn T, Technological innovation for sustainable growth: An ontological perspective, Journal of Cleaner Production 179: 31 41, (2018)

3. Gherardini F, Renzi C, Leali F, A systematic user-centred framework for engineering product design in small- and medium-sized enteIDRrises (SMEs), International Journal of Advanced Manufacturing Technology 91(5-8): 1723-1746, (2017)

4. Maheshwari S, Vohra V., Identifying critical HR practices impacting employee perception and commitment during organizational change, Journal of Organizational Change Management 28(5): 872-894, (2015).

5. Ibidunni AS, Salau OP, Falola HO, Ayeni AW, Obunabor FI, Total quality management and performance of telecommunication firms, International Business Management 11(2): 293-298, (2017)

6. Zakuan NM, Yusof SM, Laosirihhongthong T, Shaharoun, AM, Proposed relationship of TQM and organizational performance using structured equation modelling, Total Quality Management and Business Excellence 21(2): 185-203, (2010)

7. [UNIDO] United Nations Industrial Development Organization, Global value chains and development, New York (US): UNIDO Publishing, (2015)

8. [WTO] World Trade Organization, Global value chain development report 2017: measuring and analyzing the impact of GVCs on economic development, Washington DC (US): World Bank Publishing, (2017)

9. World Bank, World development report 2020: trading for development in The age of global value chains, Washington DC (US): World Bank Publishing, (2019)

10. Krisnamurthi B., Perdagangan Internasional Dan Tujuan Pembangunan Berkelanjutan (Trade and Sustainable Development Goals/SDGS), Makalah disampaikan pada 
Webinar Berseri WTO dan Analisis Kebijakan Perdagangan Kerjasama ITAPS-IE FEM IPB-ISEI Bogor Raya Kementerian Perdagangan-UNIED 12 Juni 2020, ( 2020)

11. Banga, R., Measuring Value in Global Value Chains. Unit of Economic Cooperation and Integration amongst Developing Countries (ECIDC) UNCTAD, Background Paper No. RVC-8, (2013)

12. Gereffi G, Stark KF., Global value chain analysis: a Primer, Center on globalization, governances and competitiveness, The Social Science Research Institute, (2016)

13. de Groot, N.S.P., Floriculture Worldwide Trade And Consumption Patterns, World Confference on Horticulture Research, ISHS. 17 - 20 June 1998 in Rome, Italy, (1998)

14. Simatupang, P., The Conception of Domestic Resource Cost and Net Economic Benefit for Comparative Advantage Analysis, Agribusiness Division Working Paper N0. 2/91, Centre for Agro-Socioeconomic Research, Bogor, (1991)

15. Friyatno S, Saptana. Kinerja agribisnis komoditas pertanian: kemampuan penciptaan output, nilai tambah dan keterkaitan antar sektor (analisis komparasi I-O tahun 2005 dan 2010). Jurnal Manajemen \& Agribisnis 4 (3):250-263, (2017)

16. Lindert, P. H. dan Ch. P. Kindleberger, Ekonomi Internasional (Alih Bahasa Burhanuddin Abdullah) Edisi Kedelapan. Penerbit Erlangga Jakarta, (1993)

17. Esterhuizen, Dirk, J. V. Royen and Luc D'Haese, Determinan of Competitiveness in The South African Agro-Food Fibre Complex. University of Pretoria, (2006)

18. Ma, A. S., Revealed Comparative Advantage Measure: ASEAN-China Trade Flows, Journal of Economics and Sustainable Development, 4(7), 136-145, (2013)

19. Krugman, Paul R. Dan M. Obstfeld, Ekonomi Internasional Teori dan Kebijakan. Edisi Kedua, Universitas Indonesia dan HasperCollins Publishers, (1994)

20. Salvatore, Dominick, Ekonomi Internasional, (Erlangga, Jakarta, 1994)

21. Esterhuizen, Dirk, J. V. Royen and Luc D'Haese, An Evaluation of The Competitiveness Sector in South Africa, Advanced in Competitiveness Research 16(12), 31-46, (2008)

22. Sharples J, N Milham. Long Run Competitiveness of Australian Agriculture. United States Department of Agriculture, Economic Research Competitiveness of Service, Foreign Agricultural Australian Agriculture Economic Report Number 243, Reproduced by U.S. Departement of Commerce National Technical Information Service SPRINGFIELD VA 22761, (1990)

23. Cook, M. Bredahl, M.E., Agri-business competitiveness in 1990s: Discussion, American Journal of Agricultural Economics, Vol.73 (December), pp. 1472, (1991)

24. Van Dung B, Van Hoang TT, Anh Ho TD, Le Ho TT., Concepts of AgriCompetitiveness in Theorical and Imperical Research, Journal of Development Research, 4 (1), May 2020, Page 24-33, (2020)

25. Rachman HPS, Supriyati, Saptana, Rachman B., Efisiensi daya saing usaha tani hortikultura. 2004. Dalam: Prosiding Efisiensi dan Daya Saing Sistem Usaha Tani Beberapa Komoditas Pertanian di Lahan Sawah. Bogor: Pusat Sosial Ekonomi dan Kebijakan Pertanian; p. 50-82. ISBN 979-3566-22-1, (2004)

26. Saptana, Mayrowani H, Friyatno S., Daya saing komoditas bawang putih dan cabai merah di Simalungun Sumatera Utara, Jurnal Agribisnis dan Industri Pertanian, Vol. 3(1):1-12, (2004)

27. Saptana, Tinjauan konseptual mikro-makro daya saing dan strategi pembangunan pertanian, Jurnal Forum Penelitian Agro Ekonomi, Vol. 28(1):1-18, (2010) 
28. Tufail, Sadia, Comparative Advantage of Major Crops in Punjab-Pakistan: An Application of Policy Analysis Matrix. M. Phil. A thesis submitted to the Federal Urdu University of Arts, Science and Technology, Islamabad, (2014)

29. Salam, A., S. Tufail. Competittiveness and Comparative Advantage of Important Food and Industrial Crops in Punjab: Application of Policy Analysis Matrix, Journal of International Agricultural Trade And Development, Volume 10, Number 1, page:8194, (2016)

30. Saptana, Hermanto, Sativa M, Senoadji T, Gabriella S, Ar-rozy AM, et al., Pemetaan dan Reviu Proses Bisnis Perencanaan Wilayah Hortikultura (Komoditas Bawang putih), Jakarta: Biro Perencanaan, Kementerian Pertanian; 181 p. ISBN 978-623-747060-1, (2019)

31. Monke, E.A. dan Pearson, S.R., The Policy Analysis Matrix for Agricultural Development, (Cornel University Press, Ithaca and London, 1989)

32. Monke, Eric A. and Scott R. Pearson, The Policy Analysis Matrix for Agricultural Development, (Cornel University Press, Ithaca and London, 1995)

33. Pearson, Scott; Gotsch, Carl and Bahri, Sjaful, Application of The Policy Analysis Matrix in Indonesian Agriculture, (Yayasan Obor Indonesia, Jakarta, 2004)

34. Dipokusumo, B., Studi Keunggulan Kompatarif dan Kompetitif Komoditas Bawang Putih dan Dampak Kebijakan Pemerintah Terhadap Pengembangannya Di Kabupaten Lombok Timur, Agrimansion, Vol. 5 No. 01; Nopember 2004: 35-46, (2004)

35. Kadariah, Lien Karlina dan Clive Gray, Pengantar Evaluasi Proyek. Lembaga Penerbit Fakultas Ekonomi Universitas Indonesia, Jakarta, (1978)

36. Gittinger, JP., Analisis Ekonomi Proyek-Proyek Pertanian Edisi 1986 (Terjemahan), (Universitas Indonesia Press, Jakarta, 1986)

37. Kiloes AM, Hardiyanto, Kelayakan Usahatani Bawang Putih di Berbagai Tingkat Harga Output (Feasibility of Garlic Farming at Various Price Levels of Output). J. Hort. Vol. 29 No. 2, Desember 2019 : 231-240, (2019) 
Appendix 1. Allocation of boaya into tradable inputs and domestic factors of garlic

farming in production centers in Indonesia, 2019-2019/2020

\begin{tabular}{|c|l|c|c|}
\hline \multicolumn{1}{|c|}{ No. } & Cost Type & Tradable Inputs (\%) & Domestic Factor (\%) \\
\hline A & Produktion Input & 100 & 0 \\
\hline 1 & Garlic Seeds & 0 & 100 \\
\hline 2 & Organic fertilizer & 100 & 0 \\
\hline 3 & Inorganic fertilizers & 100 & 0 \\
\hline & a. Urea/ZA & 100 & 0 \\
\hline & b. SP-36 & 100 & 0 \\
\hline & c. NPK/PONSKA & 100 & 0 \\
\hline & d. KCL & 0 & 100 \\
\hline 4 & Dolomite & 100 & 0 \\
\hline 5 & Pesticides & & 100 \\
\hline B & Labor & 0 & 100 \\
\hline 1 & Seed Preparation & 0 & 100 \\
\hline 2 & Land Processing & 0 & 100 \\
\hline 3 & Planting & 0 & 100 \\
\hline 4 & Fertilization & 0 & 100 \\
\hline 5 & Maintenance & 0 & 66.50 \\
\hline 6 & Watering & 33.50 & 66.50 \\
\hline 7 & Harvest & 33.50 & 71.50 \\
\hline 8 & Transportation & 28.50 & 100 \\
\hline 9 & Post-harvest & 0 & 100 \\
\hline C & Land Rent & 0 & \\
\hline D & Capital Interest & & \\
\hline
\end{tabular}

Table 2.1. The shadow price of input and output of garlic farming in agroecosystem of high dryland in Indonesia dry season 2019 (IDR/unit)

\begin{tabular}{|c|c|c|c|c|}
\hline No. & Cost Type & Karanganyar & Pasuruan & East Lombok \\
\hline A & Production Input & & & \\
\hline 1 & Garlic Seed (IDR/kg) & 43,000 & 44,750 & 49,350 \\
\hline 2 & Organic fertilizer (IDR/kg) & 530 & 540 & 720 \\
\hline \multirow[t]{5}{*}{3} & Inorganic fertilizer (IDR/kg) & & & \\
\hline & a. Urea/ZA & 2,539 & 2,559 & 2,439 \\
\hline & b. SP-36 & 3,308 & 3,417 & 3,297 \\
\hline & c. NPK & 5,576 & 5,585 & 5,465 \\
\hline & d. KCL & 4,390 & 4,409 & 9,600 \\
\hline 4 & Dolomite (IDR/kg) & 800 & 1,000 & 1,000 \\
\hline 5 & Pesticides (IDR/season) & $6,828,000$ & $6,548,000$ & $7,572,800$ \\
\hline 6 & Mulch & 600,000 & 600,000 & 520,000 \\
\hline $\mathrm{B}$ & Labor (IDR/day) & & & \\
\hline 1 & Seed Preparation & 50,000 & 70,000 & 70,000 \\
\hline 2 & Land Processing & 70,000 & 80,000 & 80,000 \\
\hline 3 & Mulch Installation & 70,000 & 80,000 & 80,000 \\
\hline 4 & Planting & 50,000 & 70,000 & 40,000 \\
\hline \multirow[t]{2}{*}{5} & Fertilization & & & \\
\hline & a. Basic & 70,000 & 80,000 & 40,000 \\
\hline
\end{tabular}




\begin{tabular}{|l|l|l|l|l|}
\hline & b. Phase I (Vegetatif) & 70,000 & 80,000 & 40,000 \\
\hline & c. Phase II (generatif) & 70,000 & 80,000 & 40,000 \\
\hline 6 & Maintenance & & & \\
\hline & a. Weeding (2 kali) & 50,000 & 70,000 & 40,000 \\
\hline & b. Watering & 70,000 & 80,000 & 80,000 \\
\hline & c. Pest Controlling (10 kali) & 70,000 & 80,000 & 40,000 \\
\hline 7 & Harvest (Revocation) & 70,000 & 80,000 & 40,000 \\
\hline 8 & Post-harvest & & & \\
\hline & a. Transportation & 70,000 & 80,000 & 80,000 \\
\hline & b. Grading and Sortation & 50,000 & 70,000 & 70,000 \\
\hline 9 & Land lease (IDR/ha/musim) & $8,333,333$ & $6,000,000$ & $11,690,000$ \\
\hline 10 & Capital interest (\%/musim) & 1.31 & 1.31 & 1.31 \\
\hline 11 & Garlic Output (IDR/kg) & 8178 & 8143 & 8128 \\
\hline
\end{tabular}

Table 2.2. The shadow price of input and output of garlic farming in agroecosystem of high dryland in Indonesia rainy season 2019-2020 (IDR/unit)

\begin{tabular}{|c|c|c|c|c|}
\hline No. & Cost Type & Cianjur & Karanganyar & Pasuruan \\
\hline $\mathrm{A}$ & Production Input & & & \\
\hline 1 & Garlic Seed (IDR/kg) & 53,825 & 44,800 & 4,475 \\
\hline 2 & Organic fertilizer (IDR/kg) & 632 & 530 & 540 \\
\hline \multirow[t]{5}{*}{3} & $\begin{array}{l}\text { Inorganic fertilizer } \\
(\text { IDR } / \mathrm{kg})\end{array}$ & & & \\
\hline & a. Urea/ZA & 2,469 & 2,559 & 2,569 \\
\hline & b. SP-36 & 3,327 & 3,417 & 3,427 \\
\hline & c. NPK & 5,495 & 5,585 & 5,595 \\
\hline & d. KCL & 4,309 & 4,409 & 4,409 \\
\hline 4 & Dolomite (IDR/kg) & 1,000 & 1,000 & 1,000 \\
\hline 5 & Pesticides (IDR/season) & $3,996,000$ & $8,960,000$ & $7,720,000$ \\
\hline 6 & Mulch & 680,000 & 600,000 & 600,000 \\
\hline $\mathrm{B}$ & Labor (IDR/day) & & & \\
\hline 1 & Seed Preparation & 40,000 & 70,000 & 70,000 \\
\hline 2 & Land Processing & 50,000 & 80,000 & 80,000 \\
\hline 3 & Mulch Installation & 50,000 & 80,000 & 80,000 \\
\hline 4 & Planting & 40,000 & 70,000 & 70,000 \\
\hline \multirow[t]{4}{*}{5} & Fertilization & & & \\
\hline & a. Basic & 40,000 & 80,000 & 80,000 \\
\hline & b. Phase I (Vegetatif) & 40,000 & 80,000 & 80,000 \\
\hline & c. Phase II (generatif) & 40,000 & 80,000 & 80,000 \\
\hline \multirow[t]{4}{*}{6} & Maintenance & & & \\
\hline & a. Weeding (2 kali) & 40,000 & 70,000 & 70,000 \\
\hline & b. Watering & 50,000 & 80,000 & 80,000 \\
\hline & c. Pest Controlling (10 kali) & 50,000 & 80,000 & 80,000 \\
\hline 7 & Harvest (Revocation) & 50,000 & 80,000 & 80,000 \\
\hline \multirow[t]{3}{*}{8} & Post-harvest & & & \\
\hline & a. Transportation & 50,000 & 80,000 & 80,000 \\
\hline & b. Grading and Sortation & 40,000 & 70,000 & 70,000 \\
\hline 9 & Land lease (IDR/ha/musim) & $7,500,000$ & $8,000,000$ & $6,000,000$ \\
\hline 10 & Capital interest (\%/musim) & 1.31 & 1.31 & 1.31 \\
\hline 11 & Garlic Output (IDR/kg) & 8153 & 8178 & 8143 \\
\hline
\end{tabular}


Table 3.1. Analysis of Policy Analysis Matrix (PAM) of garlic farming on dry land in Cianjur

Regency, wet season 2019

\begin{tabular}{|l|c|l|l|c|}
\hline \multirow{2}{*}{ Description } & \multirow{2}{*}{ Revenue } & \multicolumn{2}{|c|}{ Cost } & \multirow{2}{*}{ Profit } \\
\cline { 3 - 4 } & & Tradable input cost & Domestic factor cost & \\
\hline Private Cost & $120,690,000$ & $69,573,500$ & $33,476,088$ & $17,640,412$ \\
\hline Social Cost & $98,399,764$ & $61,166,900$ & $32,704,622$ & $4,528,242$ \\
\hline $\begin{array}{l}\text { Effect of } \\
\text { divergence } \\
\text { and policy }\end{array}$ & $22,290,236$ & $8,406,600$ & 771,466 & $13,112,170$ \\
\hline
\end{tabular}

Table 3.2. Analysis of Policy Analysis Matrix (PAM) of garlic farming on dry land in Karanganyar Regency, dry season 2019

\begin{tabular}{|c|c|c|c|c|}
\hline \multirow[b]{2}{*}{ Description } & \multirow[b]{2}{*}{ Revenue } & \multicolumn{2}{|c|}{ Cost } & \multirow[b]{2}{*}{ Profit } \\
\hline & & $\begin{array}{c}\text { Tradable input } \\
\text { cost }\end{array}$ & $\begin{array}{c}\text { Domestic factor } \\
\text { cost }\end{array}$ & \\
\hline Private Cost & $141,000,000$ & $45,786,500$ & $44,425,184$ & $50,788,316$ \\
\hline Social Cost & $96,092,675$ & $45,520,950$ & $48,599,739$ & $1,971,986$ \\
\hline $\begin{array}{l}\text { Effect of divergence } \\
\text { and policy }\end{array}$ & $44,907,325$ & 265,550 & $-4,174,555$ & $48,816,330$ \\
\hline
\end{tabular}

Table 3.3. Analysis of Policy Analysis Matrix (PAM) of garlic farming on dry land in Karanganyar Regency, rainy season, 2019

\begin{tabular}{|l|c|c|c|c|}
\hline \multirow{2}{*}{ Description } & \multirow{2}{*}{ Revenue } & $\begin{array}{c}|c| \\
\text { Tradable input } \\
\text { cost }\end{array}$ & $\begin{array}{c}\text { Domestic factor } \\
\text { cost }\end{array}$ & \multirow{2}{*}{ Profit } \\
\hline Private Cost & $162,288,800$ & $77,789,500$ & $59,440,687$ & $25,058,613$ \\
\hline Social Cost & $97,589,267$ & $65,370,350$ & $59,009,393$ & $-26,790,476$ \\
\hline $\begin{array}{l}\text { Effect of divergence } \\
\text { and policy }\end{array}$ & $64,699,533$ & $12,419,150$ & 431,294 & $51,849,089$ \\
\hline
\end{tabular}

Table 3.4. Analysis of Policy Analysis Matrix (PAM) of garlic farming on dry land in Pasuruan Regency, dry season 2019

\begin{tabular}{|l|c|c|c|c|}
\hline \multirow{2}{*}{ Description } & \multirow{2}{*}{ Revenue } & \multicolumn{2}{|c|}{ Cost } & \multirow{2}{*}{ Profit } \\
\cline { 3 - 4 } & & Tradable input cost & Domestic factor cost & \\
\hline Private Cost & $143,940,000$ & $44,024,500$ & $52,424,483$ & $47,491,017$ \\
\hline Social Cost & $97,676,485$ & $34,533,350$ & $52,823,483$ & $10,319,652$ \\
\hline $\begin{array}{l}\text { Effect of } \\
\text { divergence and } \\
\text { policy }\end{array}$ & $46,263,516$ & $9,491,150$ & $-399,000$ & $37,171,366$ \\
\hline
\end{tabular}


Table 3.5. Analysis of Policy Analysis Matrix (PAM) of garlic farming on dry land in

Pasuruan Regency, rainy season 2019/2020

\begin{tabular}{|l|c|r|r|r|}
\hline \multirow{2}{*}{ Description } & \multirow{2}{*}{ Revenue } & $\begin{array}{c}|c| \\
\text { Tradable input } \\
\text { cost }\end{array}$ & $\begin{array}{c}\text { Domestic factor } \\
\text { cost }\end{array}$ & \multirow{2}{*}{ Profit } \\
\hline Private Cost & $134,750,000$ & $43,739,500$ & $48,723,500$ & $42,287,000$ \\
\hline Social Cost & $78,377,338$ & $35,713,850$ & $47,774,870$ & $-5,111,383$ \\
\hline $\begin{array}{l}\text { Effect of divergence } \\
\text { and policy }\end{array}$ & $56,372,663$ & $8,025,650$ & 948,630 & $47,398,383$ \\
\hline
\end{tabular}

Table 3.6. Analysis of Policy Analysis Matrix (PAM) garlic farming on dry highland land in East Lombok Regency, dry season 2019

\begin{tabular}{|c|c|c|c|c|}
\hline \multirow[b]{2}{*}{ Description } & \multirow[b]{2}{*}{ Revenue } & \multicolumn{2}{|c|}{ Cost } & \multirow[b]{2}{*}{ Profit } \\
\hline & & $\begin{array}{c}\text { Tradable input } \\
\text { cost }\end{array}$ & $\begin{array}{c}\text { Domestic factor } \\
\text { cost }\end{array}$ & \\
\hline Private Cost & $152,512,965$ & $69,573,500$ & $33,476,088$ & $49,463,377$ \\
\hline Social Cost & $101,194,845$ & $67,241,600$ & $50,392,784$ & $-16,439,539$ \\
\hline $\begin{array}{l}\text { Effect of divergence } \\
\text { and policy }\end{array}$ & $51,318,120$ & $2,331,900$ & $-16,916,696$ & $65,902,916$ \\
\hline
\end{tabular}

